\title{
Analysis of Students Metacognitive Ability in Mathematical Problem Solving in SMP Negeri 4 Bendahara Aceh Tamiang
}

\author{
Nurdiana Fahmi ${ }^{1}$, Bornok Sinaga ${ }^{2}$, W. Rajagukguk ${ }^{3, *}$ \\ ${ }^{1}$ Education of Mathematics Post Graduate, Universitas Negeri Medan, Medan, Indonesia \\ ${ }^{2}$ Department of Mathematics Universitas Negeri Medan, Indonesia \\ *Corresponding author: Dhyanfahmi58@gmail.com
}

Received December 19, 2018; Revised January 28, 2019; Accepted February 19, 2019

\begin{abstract}
The purpose of this research is to analyze: 1) the students metacognitive ability in mathematical problems solving, 2) difficulties experienced by students' metacognitive in mathematical problem solving, 3) process of students' metacognitive answer in mathematical problem solving. This research is as qualitative descriptive research aimed to describe the students' metacognitive ability in mathematical problem solving with problem-based-learning model. Subject in this research is class VII in SMP Negeri 4 Bendahara Aceh Tamiang. The subjects consisted of four students; one in high-ability student, one medium-ability student, one low-ability student, and one with the most wrong answers. The data is obtained from the essay test and depth interview. While the object of ths research is the students' metacognitive ability in problems solving by learning mathematics with problem based learning model on the subject of integers and fractions. based on the analysis of research data, the result that: 1) the mathematical problem solving ability of students with high category at the level of metacognitive Strategic Use, the students medium category at the level of metacognitive Aware Use, and low category at the level of metacognitive Tacit Use. 2) metacognitive difficulties experienced by students in solving mathematical problems include difficulty facts, concepts, principles, and procedures.
\end{abstract}

Keywords: analysis, metacognitive ability, problem sovling, problem based learning

Cite This Article: Nurdiana Fahmi, Bornok Sinaga, and W. Rajagukguk, "Analysis of Students Metacognitive Ability in Mathematical Problem Solving in SMP Negeri 4 Bendahara Aceh Tamiang." American Journal of Educational Research, vol. 7, no. 2 (2019): 166-169. doi: 10.12691/education-7-2-8.

\section{Introduction}

Educational problems have always been an interesting issue in society recently, especially for education authorities because education is considered as an essential way to keep life values. One of educations that can be established is formal education at a school; from elementary level, secondary and higher education level with its aspects, curriculum, methods, approaches, strategies and models appropriate for every level, adequate facilities and professional human resources are interrelated aspects to achieve the planned goals. One of major issues in the field of education in Indonesia widely discussed is the low quality of education. It can be seen from the low of National Examination result held every year. This is in line with Chairani [1] who states that Mathematics is a universal science that underlies development, has an important role in various disciplines and enhances human thinking ability.

Many students assume that math is a complicated subject and it is even scary. This can be because some factors; abstract characteristics of Math, mathematic, logic, structured, hierarchy of Math concepts, started from easiest to the most complicated concepts. Moreover, another factor that makes students feel bored and unmotivated is teaching model or method used by teachers, a conventional model used almost all of the time gives negative impact for students.

Math as a basic science has strategic values in developing logical thinking skills and how to act rationally. There are 5 Math instructional goals as stated in National Council of Teacher of Mathematics ([2]: 28), they are: (1) learning to communicate (mathematical communication); (2) learning to reason (mathematical reasoning); (3) learning to solve problems (mathematical problem solving); (4) learning to associate ideas (mathematical connections); (5) establishing a positive attitude towards mathematics (positive attitudes toward mathematics).

To be able to gain those goals, someone has to manage his/her thought well, that is by exploiting his/her background knowledge, controlling and reflecting process and result of his/her own thinking in solving variety of Math problems. This process is based on students' awareness in their thinking process; the awareness about what they has mastered and how they apply the mastery, the awareness to the students' surrounding, and cognitive events including memory, thinking, curiosity and physical 
sensation. Students' success in solving Mathematic problems can also depend on how far they are able to understand Math concepts they had. It is called Metacognitive.

Metacognitive is a combination of cognitive domain levels. Sinaga in his journal "Development of Learning Devices through Problem Based Learning Model to Improve Student Metacognition Skill” states that Metacognition skills involve someone's knowledge and cognitive ability. Hofer and Pintrich, Perkin, Schneider and Lockl (in Ormrod, [3]) express that the more students know about the learning and learning process, the greater their awareness, the better the learning process and the achievements they may achieve. It can be understood that students’ Metacognitive can reflect students' thinking process. One way to increase and train the mindset of students in Mathematics is to provide tasks in solving problems. This is in line with Fauzi's study [4] entitled "Peranan Kemampuan Metakognitif dalam Memecahkan Masalah Matematika Sekolah Dasar". He expresses that students who possess Metacognitive skill will have better ability in solving problems and become reliable problem solver. Students will benefit especially to increase self-confidence and actively engaged in instructional process. Problem-based learning is used as learning process that links the daily life problems which can be solved by using mathematical concepts. In this learning process, teachers have crucial role; to provide the problems, asking questions, facilitating investigation and dialogue. In general, problem based learning consist of presenting students with authentic problem. Narrative questions are considered difficult by most of students because they require systematic steps to solve Mathematical problems. One of instructional method which suits this condition is problem based learning (PBL). According to Polya in her book How To Solve It [5], there are 4 steps in completing Mathematic problems, they are: Seeing (understanding the problem), planning (arranging the plan), doing (implementing the plan), and Checking (testing the answer). Polya's step shows that someone needs awareness in his mind (cognitive awareness) and his perception of the situation the students faced.

Surya and Syahputra [6] conclude in their study entitled Improving High-Level Thinking Skills by Development of Learning PBL Approach on the Learning Mathematics for Senior High School Students that by applying concrete instructional models such as Problem Based Learning and Problem Solving Model, it can help to improve students' higher order thinking skill in solving Math problems. This study is supported by study conducted by Amalia, Surya and Syahputra [7] in Medan State University. In their study entitled The Effectiveness of Using Problem Based Learning (PBL) in Mathematics Problem Solving Ability for Junior High School Students, they showed that average grade of students taught by using PBL was higher than those who were taught by using conventional model. So it can be concluded that instructional process which uses PBL is effective to improve students' ability in solving Math problems.

\section{Purpose of the Study}

The current study aims at: 1) finding out students 'Metacognitive abilities in solving mathematical problems, 2) Describing / examining students' difficulties in solving mathematical problems.

\section{Methodology}

\subsection{Type of Research}

This is a qualitative by using descriptive approach research.

\subsection{Subject and Object of the Research}

Subject of the study is grade 24 of VII-2 students of SMPN 4 Bendahara Banda Mulia Sub-District, Aceh Tamiang Regency 2018/2019 Academic Year, which in the process of teaching and learning implement Problem Based Learning. Object of the study is students' Metacognitive skill in solving Math problem in Integers and fraction chapter. The object of this research is obtained from the results of students' metacognitive abilities from interviews and voice recordings.

\subsection{Research Instrument}

Instrument used in this study is test of students' Metacognitive skill and interview test. Test of students' Metacognitive skill has been tested validity and reliability 0.769 with a high category so that it can be concluded that the student's Metacognitive ability test is reliable by using the Alpha-Cronbach formula. Metacognitive ability test consists of 4 item description questions related to integer and fraction material, while the interview test conducted is an unstructured interview test.

\subsection{Data Analysis}

The process of Metacognitive skills of students is analyzed by using qualitative data approach of the Miles and Huberman model [5]. Score of each test taker are determined based on the results of the test; all student answer sheets from the results of the students Metacognitive tests are collected to be assessed and scored. Scores for each student's answer are based on the students' Metacognitive skills scoring guidelines, and then the scores are categorized according to the categories used in the school.

\section{Findings}

Research Finding of Students' Metacognitive Skill in Completing Higher Order Thinking Math Problem

\begin{tabular}{|c|c|l|}
\hline No. & Aspect & \multicolumn{1}{|c|}{ Research Finding } \\
\hline 1 & Fact & $\begin{array}{l}\text { Students are able to understand the use of Math } \\
\text { symbols } \\
\text { Students are able to design Math model of } \\
\text { problems given }\end{array}$ \\
\hline 2 & Concept & $\begin{array}{l}\text { Students are able to apply the concept of integer } \\
\text { operations and fractions in solving problems given }\end{array}$ \\
\hline 3 & Principle & $\begin{array}{l}\text { Students are able to apply Mathematic formulas or } \\
\text { rules in solving mathematical problems. } \\
\text { Students are able to connect the concepts provided } \\
\text { to solve problems }\end{array}$ \\
\hline 4 & Procedure & $\begin{array}{l}\text { Students are able to present steps for solving } \\
\text { problems in systematically and correctly } \\
\text { Students are careful in carrying out calculations in } \\
\text { presenting problems }\end{array}$ \\
\hline
\end{tabular}


Research Findings of Metacognitive Skills in Resolving Mathematical Problems of Students with Moderate Ability

\begin{tabular}{|c|c|l|}
\hline No. & Aspect & Research Finding \\
\hline 1 & Fact & $\begin{array}{l}\text { Students are able to understand the use of } \\
\text { Mathematic symbols } \\
\text { Students are able to design Mathematic models in } \\
\text { solving problems given }\end{array}$ \\
\hline 2 & Concept & $\begin{array}{l}\text { Students are able to apply the concept of integer } \\
\text { operations and fractions in solving problems given }\end{array}$ \\
\hline 3 & Principle & $\begin{array}{l}\text { Students are able to apply mathematical formulas } \\
\text { or rules in solving problems }\end{array}$ \\
\hline 4 & Procedure & $\begin{array}{l}\text { Students do not carefully present calculations in } \\
\text { solving problems } \\
\text { Students are not able to create strategies to solve } \\
\text { problems effectively and efficiently }\end{array}$ \\
\hline
\end{tabular}

Research Findings of Metacognitive Skill in Solving Mathematic Problems of Students with Low Mathematic Abilities

\begin{tabular}{|c|l|l|}
\hline No. & Aspects & Research Findings \\
\hline 1 & Fact & $\begin{array}{l}\text { - Students are unable to understand the use of } \\
\text { Mathematic symbols } \\
\text { - Students are not able to design Mathematic } \\
\text { models in solving problems given }\end{array}$ \\
\hline 2 & Concept & $\begin{array}{l}\text { - Students are not able to apply the concept of } \\
\text { integer and fraction operations in solving } \\
\text { problems given }\end{array}$ \\
\hline 3 & Principle & $\begin{array}{l}\text { - Students are unable to apply Mathematic } \\
\text { formulas or theorems in solving problems }\end{array}$ \\
\hline 4 & Procedure & $\begin{array}{l}\text { - Students are not able to present steps to } \\
\text { solve problems correctly } \\
\text { Students are not able to create effective and } \\
\text { efficient strategies }\end{array}$ \\
\hline
\end{tabular}

Research Findings of Metacognitive Abilities in Solving Mathematical Problems of Students with Many Errors

\begin{tabular}{|c|c|c|}
\hline 1 & Fact & $\begin{array}{l}\text { - Students are able to understand the use of } \\
\text { Mathematic symbols } \\
\text { - Students are able to design Mathematic models of } \\
\text { problems given }\end{array}$ \\
\hline 2 & Concept & $\begin{array}{l}\text { - Students are able to apply the operation concepts to } \\
\text { calculate integers and fractions }\end{array}$ \\
\hline 3 & Principle & $\begin{array}{l}\text { - Students are unable to apply Mathematic formulas } \\
\text { or theorems in solving problems } \\
\text { - Students are not able to connect the concepts to } \\
\text { solve the problem given }\end{array}$ \\
\hline 4 & Procedure & $\begin{array}{l}\text { - Students are not able to present steps in solving } \\
\text { problems } \\
\text { - Students do not carefully carry out calculations in } \\
\text { presenting resolving problems } \\
\text { - Students are not able to develop problem solving } \\
\text { strategies effectively and efficiently }\end{array}$ \\
\hline
\end{tabular}

\section{Discussion}

Metacognitive can be developed by problem solving as stated by Sinaga [8] "Metacognitive is an important part of problem solving" in which it can be seen through three basic elements. NCTM [2] proposes that three basic elements of metacognitive especially in completing tasks are (i) developing a plan of action, (ii) regulating or monitoring actions, (iii) and evaluating actions. Napitupulu ([9]: 120) asserts that "problem-based learning is one of the learning approaches that promotes the improvement and development of children's competencies in reasoning and solving problems".

Astriani, Surya, and Syahputra [10] conclude that average of students' ability in solving problem through problem based learning is higher than those who are in conventional learning. Based on data of Metacognitive skills, there is a student or $4 \%$ of student who have Metacognitive skills at Reflective use level, 5 students or about $20 \%$ of students at strategic use level, 10 students or $40 \%$ of students at Aware use level and 9 students or $36 \%$ of students at tacit use level.

\section{Conclusion}

Students with high level ability of solving Math problem are at Reflective use and strategic use of Metacognitive skills. Students who have average level ability of solving Math problem are at aware of Metacognitive skills. Students who have lower level ability of solving Math problem are at tacit use and strategic use of Metacognitive skills. Metacognitive problems encountered by students in completing Mathematic problems are: factual problems, it is a problem in mastering Mathematic symbols in completing problems and difficulties to present symbols for designing Mathematic models. Conceptual difficulty; it is a difficulty in applying operation concepts to calculate integers and fractions to solve problems. Procedural difficulty is the difficulty in presenting steps in solving problems and difficulty in arranging strategies to solve problems effectively and efficiently.

\section{Recommendation}

Teachers are suggested to establish learning environment which allows students to express their Mathematic ideas by using their own language and ways so they want to argue and feel confident. Teachers should provide them more opportunities to dig deeper their ability when they are having group discussion so the discussion runs well.

\section{References}

[1] Chairani, Z. 2016. Metakognisi siswa dalam pemecahan masalah matematika. Yogyakarta : Deepublish.

[2] National Council of Teachers of Mathematics (NCTM). 2000. Principles and Standards for School Mathematics. Reston. VA: NCTM.

[3] Ormrod, J. 2008. Psikologi Pendidikan Membantu siswa Tumbuh dan Berkembang Edisi keenam. Jakarta : Erlangga.

[4] Fauzi, Kms. 2009. Peranan kemampuan metakognitif dalam pemecahan masalah matematika sekolah dasar. Jurnal kultura, 10(1). pp.1166. ISSN 1411-0229.

[5] Moleong, J. Lexy. 2013. Metodologi Penelitian Kualitatif. Edisi Revisi. Bandung: Remaja Rosda Karya.

[6] Surya, E and Syahputra, E. 2017. Improving High-Level Thinking Skills by Development of Learning PBL Approach on the Learning Mathematics for Senior High School.

[7] Amalia, E; Surya, E \& Syahputra, E. 2017. The Effectivenessof Using Prob;em Based Learning(PBL) in Mathematics Problem Solving Ability for Junior High School Students. www.ijariie.com. Vol 3, Issue -2.

[8] Sinaga, B. (2017). Development of learning devices through problem based learning model to improve student metacognition skill. Vol 8 no 24. International knowledge sharing platform . www.iiste.org.

[9] Napitupulu, E, E. 2011. Pengaruh Pembelajaran Berbasis Masalah Atas Kemampuan Penalaran dan Pemecahan Masalah Matematis Serta Sikap Terhadap Matematika Siswa Sekolah Menengah. Disertasi PPs Universitas Pendidikan Bandung 
[10] Astriani, N, Surya, E, Syahputra, E. 2017. The Effect Of Problem Based Learning To Student's Mathematical Problem Solving Ability. International Journal Of Advance Research And
Innovative Ideas In Eduation. Vol. 3, Issue-2

[11] Polya, G. 1973. "How to solve $1 t$ ", $2^{\text {nd }}$ ed. New Jersey: Pricenton University Press.

C The Author(s) 2019. This article is an open access article distributed under the terms and conditions of the Creative Commons Attribution (CC BY) license (http://creativecommons.org/licenses/by/4.0/). 